\title{
Chapter 4 The Legacy of the Mandates System of the League of Nations
}

\author{
Mamadou Hébié" / Paula Baldini Miranda da Cruz***
}

\section{Introduction}

The mandates system of the League of Nations was based on two principles which were considered to be of paramount importance: the principle of non-annexation of the territories of the defeated powers, and the principle that the well-being and development of the populations inhabiting those territories formed 'a sacred trust of civilization.' ${ }^{1}$ Both principles went against long-standing practices of European powers relating to the conquest and the treatment of the populations of colonial territories. This chapter examines the legacy of the mandates system based on the motives underlying the consecration of these two principles during the peace conferences, as well as its implementation in an international society that had never seen a world without colonies and conquests. It will show how the mandates system infused new ideas in international relations (2), while still remaining embedded in the traditional framework justifying European colonialism (3).

\section{The Innovative Character of the Mandates System of the League of Nations}

International law recognized the right to acquire territorial sovereignty upon a lawful use of force, even in the relations between member states of the European Family of Nations. Except for the case of debellatio, ${ }^{2}$ where '[a] peace treaty [was] not needed nor customary nor even very easy to con-

* Special Assistant to the President of the International Court of Justice.

* PhD candidate at Leiden University, Netherlands.

1 International Status of South-West Africa (Advisory Opinion) [1950] ICJ Rep, at 131.

2 It was with reference to debellatio that the Permanent Court of International Justice held that: 'Conquest only operates as a cause of loss of sovereignty when there is war between two States and by reason of the defeat of one of them sovereignty over territory passes from the loser to the victorious State.' Legal Status of Eastern Greenland (Denmark/Norway) (1933) PCIJ Rep Series AB no 22, 47. 
ceive juristically', ${ }^{3}$ the acquisition of territorial sovereignty in the course of a lawful war between member states of the European Family of Nations required the conclusion of a peace treaty. ${ }^{4}$ Established as a requirement since the 1713 Utrecht Peace Treaty, ${ }^{5}$ the conclusion of a peace treaty extinguished the right of postliminium, that is to say, the right of the defeated state to attempt to recover the territory lost, forcibly if necessary. ${ }^{6}$ Before the peace conferences, only Latin-American states had attempted to establish a general rule prohibiting the recognition of the acquisition of territorial sovereignty through force. ${ }^{7}$

The mandates system marks a departure from the practice of victorious states acquiring territorial gains from defeated powers through peace treaties (2.1.). Mandatory powers were granted only administering powers in the territories subject to this regime. The scope of those rights was based on the content of the treaties conferring the mandate and compliance with the obligations imposed in favour of the populations of territories under mandate (2.2.). The system was completed by oversight mechanisms (2.3.).

\subsection{The Principle of Non-Annexation of Territories Upon Military Victory}

Since the beginning of the war, the Allied powers ${ }^{8}$ presumed that their victory would entitle them to acquire territorial gains. ${ }^{9}$ For this purpose, they

3 Jan HW Verzijl, International Law in Historical Perspective (vol 3, Sijthoff 1970) 361.

4 See Marcelo G Kohen and Mamadou Hébié, 'Territorial Conflicts and Their International Legal Framework' in Marcelo G Kohen and Mamadou Hébié (eds), Research Handbook on Territorial Disputes in international Law (Elgar 2018) 22-24.

5 See art X of the Treaty of Peace and Friendship Between Great Britain and Spain (signed 13 July 1713) 28 CTS 295.

6 Emer de Vattel, The Law of Nations or Principles of the Law of Nature Applied to the Conduct and Affairs of Nations and Sovereigns with Three Early Essays of the Origin and Nature of Natural Law and on Luxury (Book III, Chapter XVI, Liberty Fund 2008) 607 [212].

7 See International American Conference, 'Recommendation on the Right of Conquest' (1890) 11 Reports of Committees and Discussions Thereon 1121.

8 For the purposes of this contribution, the term 'Allied powers' will refer to the Principal Allied and Associated powers as defined in the Treaty of Versailles-that is, the United States, the British Empire, France, Italy, and Japan (preamble to the Treaty of Peace between the Allied and Associated Powers and Germany (signed 28 June 1919) 225 CTS 188).

9 See 'The Ambassador in Austria-Hungary (Penfield) to the Secretary of State, 12 January 1917', in Office of the Historian, Papers Relating to the Foreign Relations of the United States, 1917: Supp 1 (The World War), File no 763.72119/368< <ttps://histo 
signed, during the war, several secret treaties establishing the terms of their mutual support, including how they would divide the spoils of war. ${ }^{10}$ Promises of territorial concessions and threats of territorial dismemberment were used as bait to recruit states to join their side in the war or to try to prevent them from joining their enemies. Whereas Italy and Romania joined the Allied powers upon promises of territorial compensation, ${ }^{11}$ Turkey was warned that it would keep its territorial integrity only if it stayed neutral during the war. ${ }^{12}$ Even the United States attempted to negotiate an early peace with Austria-Hungary by promising the preservation of its territorial integrity upon the end of the war. ${ }^{13}$ The proposal was unsuccessful, as Austria-Hungary refused to negotiate peace without its allies. ${ }^{14}$ In line with the old spirit of conquest, France and Great Britain occupied militarily the territories they intended to acquire at the end of the war. ${ }^{15}$

It is therefore somewhat surprising that the peace settlement negotiations consecrated the principle of non-annexation. This achievement is due to the position adopted by the United States during the negotiations. On 8 January 1918, president Wilson made a speech identifying the principles to govern the peace negotiations to end World War I. In one breath, Wilson rejected the plans of the other Allied powers to acquire sovereignty at the

ry.state.gov/historicaldocuments/frus1917Supp01v 01/d10> accessed 21 November 2018.

10 'Telegram from the Russian Minister of Foreign Affairs (M Sazonoff) to the Russian Ambassador at Paris 5 March 1915, in Frederick Seymour Cocks, The Secret Treaties and Understandings: Text of the Available Documents with Introductory Comments and Explanatory Notes (Union of Democratic Control 1918) 17-18; 'Telegrams exchanged between French and Russian representatives between 24 February 1916 and 20 February 1917', in ibid 65-74.

11 See arts 4-8, 9-13 of the Treaty with Italy (Britain, France, Russia, and Italy) (signed 26 April 1925), in ibid 30-41; See also the communications exchanged between Romanian and Russian officials between 12 and 18 August 1916, in ibid 49-59.

12 'Speech of Sir Edward Grey in the House of Commons (13 October 1915), and internal communications of Russia from 6 March 2017, in ibid 41-47.

13 'The Secretary of State to the Ambassador in Austria-Hungary (Penfield)' (22 February 1917) in Office of the Historian (n 9) File no 763.72119/10094a <https:// history.state.gov/historicaldocuments/frus1917Supp01v 01/d50> accessed 21 November 2018.

14 The Ambassador in Austria-Hungary (Penfield) to the Secretary of State (27 February 1917) ibid, File no 763.72119/8389 <https://history.state.gov/historicaldo cuments/frus1917Supp01v 01/d53> accessed 21 November 2018.

15 See Quincy Wright, Mandates Under the League of Nations (University of Chicago Press 1930) 26-27. 
end of the war, as well as the secret treaties which supported them. For Wilson:

The day of conquest and aggrandizement is gone by; so is also the day of secret covenants entered into in the interest of particular governments and likely at some unlooked-for moment to upset the peace of the world. ${ }^{16}$

Instead, Wilson explained in the fifth point of the Fourteen Points that the United States aimed for

[a] free, open-minded, and absolutely impartial adjustment of all colonial claims, based on a strict observance of the principle that in determining all such questions of sovereignty the interests of the populations concerned must have equal weight with the equitable claims of the government whose title is to be determined. ${ }^{17}$

One month after the Fourteen Points speech, Wilson was again before the United States Congress to explain his goals in the peace negotiations. $\mathrm{He}$ listed four of them, which would replace the equilibrium of power among European states in the mission of maintaining international peace. In the new world order that Wilson intended to establish,

peoples and provinces [would not] be bartered about from sovereignty to sovereignty as if they were mere chattels and pawns in a game, even the great game, now forever discredited, of the balance of power. ${ }^{18}$

At the end of the war, the Allied powers secured the renunciation by Germany and the Ottoman Empire to their titles of sovereignty over the territories they intended to place under the mandates system. Germany renounced to its titles over its colonies by virtue of Article 119 of the Treaty of Versailles. Although the Ottoman Empire had agreed to the loss of its territory through the 1920 Treaty of Sèvres, it failed to ratify this agreement. Therefore, it was only in the 1923 Treaty of Lausanne that Turkey renounced its titles of sovereignty over territories that were subsequently placed under the mandates system. ${ }^{19}$

16 Wilson to Congress (8 January 1918) 45 The Papers of Woodrow Wilson 534-539.

17 ibid.

18 Wilson to Congress (11 February 1918) 46 The Papers of Woodrow Wilson 318324.

19 Territorial Sovereignty and Scope of the Dispute (Eritrea/Yemen) (Award in the First Stage of Proceedings) [1998] 22 RIAA 209 [151]-[152]. 
The renunciation by Germany and the Ottoman Empire to their titles of territorial sovereignty did not, however, lead to the annexation of these territories by the Allied powers. Despite difficult negotiations with Great Britain and France which threatened not to support the creation of a League of Nations, ${ }^{20}$ Wilson remained firm in his stance against the annexation of the territories of the defeated powers. Only when annexation ceased to be an option due to domestic and international pressure, Great Britain and France expressed support for the mandates system, which they perceived as a lesser evil. ${ }^{21}$ As a consequence, the only territory of Germany that was attributed to an Allied power following the First World War was Alsace-Lorraine. However, the Allied powers did not see the transfer of Alsace-Lorraine to France as an acquisition of territorial sovereignty through conquest. Instead, they considered the conquest of this territory by Germany in 1871 as null and void ab initio, characterizing it as the result of an unlawful war. The return of Alsace-Lorraine to France was therefore described as a 'moral obligation to redress the wrong done by Germany in $1871 .^{22}$

Mandatory powers rarely attempted to proclaim formally their sovereignty on territories under the mandates system. When they did so, the League systematically rejected these claims. In 1926, South Africa claimed openly that it possessed 'sovereignty over the Territory of SouthWest Africa' in a boundary treaty with Portugal. ${ }^{23}$ This claim caused some commotion among the members of the Permanent Mandates Commission and prompted a firm rebuttal by the Council. ${ }^{24}$ In 1927, a representative of New Zealand made a public speech referring to Western Samoa as 'part of the British Empire' and its inhabitants as 'British subjects'. The choice of words was unfortunate. Again, the Permanent Mandates Commission was vigilant and requested explanations from New Zealand on this statement

20 Robert Lansing, The Big Four and Others of the Peace Conference (Houghton Mifflin Company 1921) 50-52.

21 See Michael D Callahan, Mandates and Empire: The League of Nations and Africa, 1914-1931 (Sussex Academic Press 2008) 42-43.

22 Introduction to Section V of the 1919 Treaty of Peace with Germany (n 8).

23 'Agreement Between the Government of the Union of South Africa and the Government of the Republic of Portugal in Relation to the Boundary Between the Mandated Territory of South-West Africa and Angola (22 June 1926)' 7 LNOJ 1530, 1533.

24 League of Nations, General Council, 58th session, 2nd meeting (13 January 1930) 11 LNOJ 69, 69. 
before clarifying that this country did not hold sovereignty over Western Samoa. ${ }^{25}$

Hence, despite some resistance, the mandates system was able to establish the principle of non-annexation upon military victory. The choice for the principle of non-annexation was rather voluntary and cannot be construed as imposed by or reflecting a general international law rule at that time. Nonetheless, its adoption was a strong policy choice that would evolve later into the principle of non-recognition of the acquisition of territories by force. ${ }^{26}$ The ensuing internationalization of the status of territories under mandate was coupled with the recognition of certain rights to the populations living therein.

\subsection{The Internationalization of the Treatment of Certain Colonial Populations}

Traditionally, international law contained primarily rules applicable to the relations between states. Thus, in the Lotus (France $v$ Turkey) case, the Permanent Court of International Justice held peremptorily that '[i]nternational law governs relations between independent States.27 The rare exceptions were a few rules regarding minorities, ${ }^{28}$ the capitulation regimes, ${ }^{29}$ and those relating to slavery. ${ }^{30}$ Issues relating to the domestic treatment of

25 League of Nations, Permanent Mandates Commission, 'Report on the Work of the Twelfth Session of the Commission', (1927) Doc C.564.1927.VI, 7.

26 See Legal Consequences of the Construction of a Wall in the Occupied Palestinian Territory (Advisory Opinion) [2004] ICJ Rep 171 [87] (holding that 'the principles as to the use of force incorporated in the Charter reflect customary international law ...; the same is true of its corollary entailing the illegality of territorial acquisition resulting from the threat or use of force.')

27 The case of the SS 'Lotus' (Judgement) PCIJ Rep Ser A no 10, 18.

28 See, eg, art 5(31) and (32) of the Treaty of Osnabruck (signed 24 October 1648) 1 CTS 231.

29 See, eg, Treaty of Amity and Commerce Between Japan and the United States (signed 29 July 1858) 119 CTS 253.

30 See, eg, the Treaty Between Great Britain, Austria, France, Prussia, and Russia, for the Suppression of the African Slave Trade (signed 20 December 1841) 92 CTS 437; Treaty Between Great Britain and Venezuela, for the Abolition of the Slave Trade (signed 15 March 1839) 88 CTS 359. See, especially, the 1815 declaration by Austria, France, Portugal, Prussia, Russia, Spain, Sweden-Norway, and the United Kingdom, during the Congress of Vienna (Declaration of the Eight Courts Relative to the Universal Abolition of the Slave Trade) (signed 8 February 1815) 63 CTS 473. 
individuals which were not governed by international agreements were considered as falling under the domaine réservé of states. ${ }^{31}$

The end of the First World War witnessed a substantial increase in the number of treaties concluded for the protection of minorities. This increase was a consequence of the need to protect at the international level the minority groups in the states created in the territories formerly under the sovereignty of the Austro-Hungarian Empire. ${ }^{32}$ Revealing the legal perceptions that existed at that time, the Permanent Court of International Justice explained in the advisory opinion relating to the Jurisdiction of the Danzig Tribunals that

... an international agreement, cannot, as such, create direct rights and obligations for private individuals. But it cannot be disputed that the very object of an international agreement, according to the intention of the contracting Parties, may be the adoption by the Parties of some definite rules creating individual rights and obligations and enforceable by the national courts. ${ }^{33}$

In cases not covered by existing treaties, states enjoyed almost full discretion when it came to dealing with their nationals. The international legal system had not yet matured to reach the stage where it could be held that '[i]t would be a travesty of law and a betrayal of the universal need for jus-

31 Nationality Decrees in Tunisia and Morocco (Advisory Opinion) PCIJ Rep ser B no 4, 26.

32 See, among others, arts 62-69 of Treaty of Peace Between the Principal Allied and Associated Powers and Austria (signed 10 September 1919) 226 CTS 8; arts 49-57 of the Treaty of Peace Between the Allied and Associated Powers and Bulgaria (signed 27 November 1919) 226 CTS 332; arts 54-60 of the Treaty of Peace Between the Allied and Associated Powers and Hungary (signed 4 June 1920) (1923) 113 BSP 486; arts 37-45 of the Treaty of Peace with Turkey (signed 24 July 1923) 28 LNTS 11; art 2, 7-12 of the Minorities Treaty Between the Principal Allied and Associated Powers and Poland (signed 18 June 1919) 225 CTS 412; arts 2, 7-11 of the Treaty Between the Principal Allied and Associated Powers and the SerbCroat-Slovene state (signed 10 September 1919) 226 CTS 182; arts 2, 7-14 of the Treaty Between the Principal Allied and Associated Powers and Czechoslovakia (signed 10 September 1919) 226 CTS 170; arts 2, 8-12 of the Minorities Treaty Between the Principal Allied and Associated Powers and Romania (signed 9 December 1919) 226 CTS 447; arts 2, 7-16 of the Treaty Between the Principal Allied and Associated Powers and Greece (signed 10 August 1920) 13 UNTS 196.

33 Jurisdiction of the Court of Danzig (Advisory Opinion) PCIJ Rep ser B no 15, 17-18. 
tice, should the concept of State sovereignty be allowed to be raised successfully against human rights. ${ }^{34}$

In the Bernheim case which arose from the enactment of discriminatory measures against 'non-Aryans', especially Jews, Germany claimed before the Council of the League of Nations that it had a right to treat its citizens as it saw fit. ${ }^{35}$ When examining the complaint submitted by Mr Bernheim, the League of Nations Council concluded that the laws of Germany had violated the German-Polish Convention of 15 May 1922 because the measures adopted discriminated against the Jewish minority living in Upper Silesia. ${ }^{36}$ However, the Council was careful to emphasize that the German-Polish agreement applied only to the region of Upper Silesia. As such, it did not apply to minority groups residing in the rest of the territory of Germany. For the Council, Germany could fix the breach of its international obligations if it excluded the Upper Silesian region from the scope of application of the discriminatory laws. ${ }^{37}$

The mandates system expanded the 'very loosely-set bars' of the 'iron cage $^{38}$ through which individuals could reach for international legal protection by granting rights to the populations of territories under mandate and imposing obligations bearing upon mandatory powers. ${ }^{39}$ Some of the rights arose directly from Article 22 of the League of Nations Covenant. This provision guaranteed that the populations of territories under B and $\mathrm{C}$ mandates would have 'freedom of conscience and religion', while prohibiting 'abuses such as the slave trade, the arms traffic and the liquor traf-

34 International Criminal Tribunal for the Former Yugoslavia, The Prosecutor $v$ Dusko Tadic a/k/a 'Dule', Decision on the Defence Motion for Interlocutory Appeal on Jurisdiction, IT-94-1-AR72, Appeals Chamber, Decision of 2 October 1995, para 58.

35 Franz Bernheim, 'The Bernheim Petition to the League of Nations' (1934/1935) 35 Am Jewish YB 74.

36 For the text of the Convention on Upper Silesia, see 'Deutsch-polnisches Abkommen über Oberschlesien' [1922](2) Reichsgesetzblatt 238, in particular arts 66-67, 75, 80, and 83. See also Erpelding (ch 12).

37 League of Nations, 'Application of the German-Polish Convention of May 15th, 1933, Relating to Upper Silesia, Opinion of the Committee of Jurists' (1934/1935) 35 Am Jewish YB 99.

38 See Nicolas Politis, The New Aspects of International Law (Washington 1928) 31-32.

39 We use the term 'right' in a manner similar to that of the International Court of Justice in the Lagrand case concerning the right to consular notification. LaGrand (Germany $v$ United States of America) (Judgment) [2001] ICJ Rep 497 [89]. 
fic.' Other rights arose from specific provisions of mandate treaties and included the right to education, ${ }^{40}$ as well as the prohibition of forced labor. ${ }^{41}$

By providing rights based on international treaties to the populations of territories under mandate, the mandates system removed the question of their treatment on these matters from the domaine réservé of the mandatory powers. In theory, all states parties to the mandates system were therefore entitled to request compliance with the legal obligations arising under these agreements. Furthermore, all mandate treaties had a compromissory clause granting jurisdiction to the Permanent Court of International Justice over disputes arising from their interpretation and application. ${ }^{42}$ During the League era, these provisions were not used to secure compliance with the rights of the populations under mandate. In the 1960s, Ethiopia and Liberia relied on the compromissory clause in South Africa's mandate agreement to hold this country accountable for the implementation of racist policies in South West Africa. Reversing its 1962 preliminary objections decision, ${ }^{43}$ the International Court of Justice held that these jurisdictional clauses were not sufficient for the Court to decide on the case at the merits stage. Ethiopia and Liberia were required to demonstrate their right to request compliance by South Africa with the obligations stipulated in favour of the populations of territories under the mandate. The Court held

40 See, eg, art 8 of the 'French Mandate for Syria and the Lebanon, 24 July 1922' Doc C.528.M.313.

41 See, eg, art 6 of the 'British Mandate for East Africa, 1 October 1922', Doc C.449(1)a.M.345(a).1922.VI; art 4 of 'British Mandate for Cameroons, 1 October 1922', Doc C449.1.C.M.345(C)1922.VI.

42 All mandates had a dispute resolution clause granting jurisdiction over all disputes on the interpretation of mandate obligations. See, eg, art 17 of the Treaty of Alliance (Great Britain-Iraq) (signed 10 October 1922) 17 LNTS 629; art 12 of the 'French Mandate for Togoland, 12 October 1922', C.449(1)b.M.345(b).1922.VI.

43 In the preliminary objections decision, the Court had held - rightly it is submitted that 'The language used [in the compromissory clause of the mandate agreement] is broad, clear and precise: it gives rise to no ambiguity and it permits of no exception. It refers to any dispute whatever relating not to any one particular provision or provisions, but to "the provisions" of the Mandate, obviously meaning al1 or any provisions, whether they relate to substantive obligations of the Mandatory toward the inhabitants of the Territory or toward the other Members of the League or to its obligation to submit to supervision by the League under Article 6 or to protection under Article 7 itself. For the manifest scope and purport of the provisions of this Article indicate that the Members of the League were understood to have a legal right or interest in the observance by the Mandatory of its obligations both toward the inhabitants of the Mandated Territory, and toward the League of Nations and its Members'. South West Africa Cases (Ethiopia v South Africa; Liberia $v$ South Africa) (Preliminary Objections) [1962] ICJ Rep 343. 
that member states of the League, unlike the League itself, did not have locus standi to require such compliance. ${ }^{44}$

Besides the possible recourse to the Permanent Court of International Justice, which was never used in practice, ${ }^{45}$ the mandates system also provided for an institutional framework to monitor compliance with the obligations under the mandates system.

\subsection{The Institutionalization of a Droit de Regard with Respect to the Treatment of Certain Colonial Populations}

The web of treaties that composed the mandates system was anchored in Article 22 of the Covenant of the League of Nations. ${ }^{46}$ Article 22 specified that the powers of the mandatories over the territories under mandate would be 'previously agreed upon by the members of the League' or 'explicitly defined on each case by the Council [of the League of Nations]. Moreover, Article 22 of the Covenant indicated that mandatories were acting 'on behalf of the League.' The legal interest of the League of Nations in the implementation of the mandate treaties was therefore not contentious. ${ }^{47}$

Foreshadowing some contemporary human rights monitoring bodies, the League institutionalized its right to monitor compliance with the obligations arising under the mandates through a subsidiary body. Established in 1920 under Article 22 of the Covenant, the Permanent Mandates Com-

44 South West Africa Cases (Ethiopia v South Africa; Liberia v. South Africa) (Judgment) [1966] ICJ Rep 28-30, [33]-[36].

45 The International Court of Justice subsequently changed its approach to the question of locus standi in Belgium v Senegal (Questions relating to the Obligation to Prosecute or Extradite (Belgium v Senegal) (Judgment) [2012] ICJ Rep [68]-[69]) following the recognition by the Court of erga omnes obligations in the Barcelona traction case (Barcelona Traction, Light and Power Company, Limited (Belgium v Spain) (Judgment of 5 February 1970) [1970] ICJ Rep [33]. Interestingly, in the Whaling case, the Court seems to have considered as irrelevant, at least for this case, the question of the locus standi of a party to a multilateral treaty to request compliance with the obligations therein (Whaling in the Antarctic (Australia $v$ Japan: New Zealand intervening) (Judgment) [2014] ICJ Rep, 226).

46 Thus, it has been contended that the mandates system had a 'conventional and constitutional character' See, Giovanni Distefano, 'Article 22' in Robert Kolb, Djacoba Liva Tehindrazanarivelo \& Markus G Schmidt (eds), Commentaire sur le Pacte de la Société des Nations (Bruylant 2015) 896-907.

47 See South West Africa (1966) (n 44) [26]. 
mission was an advisory organ. Initially composed of nine experts in colonial administration, the Commission's membership expanded subsequently to ten members, in addition to a representative of the International Labour Organization who participated in discussions relating to labor issues. The members of the Commission were mostly nationals from nonmandatory powers. ${ }^{48}$ To avoid conflicts of interest, they could not hold any political appointment during the duration of their term in the Commission. Six out of the ten members of the Commission had to be nationals from non-mandatory states. ${ }^{49}$ Although the Commission was not a political organ and its members were prohibited from holding governmental position, it was unusual for commissioners to criticize the actions of the state of their nationality. ${ }^{50}$

The Commission exercised its control mostly based on periodical reports submitted by mandatory powers and the individual petitioning mechanism. Reports were presented annually by mandatories to the Commission and provided general information on steps and measures taken in the previous year to fulfill their obligations under their mandate agreements. The Secretariat of the League could also provide additional information. In addition to the annual reports, the Commission could request special reports relating to emergencies, as it did during the Bondelswarts rebellion in South West Africa. ${ }^{51}$

Populations of territories under mandate could petition the League and report situations of misconduct and lack of performance by mandatory powers of their obligations. Before 1923, individual complaints regarding mandates were informally submitted to the Secretariat, but there was no assurance that they would be, indeed, examined by the League or by the Commission. After 1923, the Council formalized a procedure whereby individuals of territories under the mandates system could petition to the Permanent Mandates Commission. ${ }^{52}$ However, this procedure had limitations. There was no protection for petitioners against retaliation, as anony-

48 Art A of the 'Constitution of the Permanent Mandates Commission' (1920) 1 (8) LNOJ 87.

49 ibid.

50 On the role of the Permanent Mandates Commission and its members, see Susan Pedersen, The Guardians: The League of Nations and the Crisis of Empire (OUP 2015) 58-69.

51 LoN, Permanent Mandates Commission, 'Minutes of the Third Session, 20 July10 August 1923' Doc A.46.1923.VI[A], 290-296.

52 LoN, Council, 'Twenty-Third Session' (1923) YB of the League of Nations 57-58. 
mous petitions were not accepted. ${ }^{53}$ Furthermore, petitioners were required to submit their petitions through mandatory powers. The disclosure allowed the latter to have access to the information in the petition, and to append their comments before forwarding it to the League. ${ }^{54}$

Although evidence of retaliation against petitioners is hard to find, it was not uncommon for mandatory powers to discourage individuals from petitioning the League. ${ }^{55}$ The system anticipated this possibility by authorizing petitioners to forward a copy of their petitions directly to the Secretariat of the League. Nevertheless, informing mandatory powers of the content of the petitions gave them the opportunity to hamper procedures by, for instance, withholding evidence of their misconduct. ${ }^{56}$ The complexity and restrictions of the petitioning system led members of the League Council to question its effectiveness. ${ }^{57}$

The Commission could not issue binding decisions. Its primary role was, on the one hand, to interpret the mandates treaties and relating documents, and, on the other hand, to formulate standards of best practices. ${ }^{58}$ Nonetheless, the mere exercise of oversight and scrutiny by the Commission influenced mandatory powers and their colonial agents to take their

53 LoN, Permanent Mandates Commission, 'Minutes of the Seventh Session' (19-30 October 1925) Doc C.648.M.237.1925.VI[A], 133-134.

54 LoN, Council, 'Petitions from Mandated Territories', art A, available in 'TwentyThird Session' (1923) (n 52) 57-58; LoN, 'Procedure in respect of Petitions Regarding Inhabitants of Mandated Territories, 1 February 1923', C.37.M.91.1923.XI.

55 See eg, when New Zealand was called in to provide explanations for why it withheld information from the Permanent Mandates Commission regarding disturbances and complaints by the Western Samoa population. LoN, Permanent Mandates Commission, 'Minutes of the Twelfth Session, 24 October-11 November 1927' (1928) 9 LNOJ 1220, 1222, and LoN, Permanent Mandates Commission, Report on the Twelfth Session (1927) (n 25) 7. For a more detailed account of the incident, see Pedersen (2015) (n 50) 170.

56 See LoN, Permanent Mandates Commission, 'Minutes of Twelfth Session (1927)' (n 55) 1222.

57 Thus, the Norwegian representative observed during the Council's fifth session that ' $[\mathrm{h}] \mathrm{e}$ had occasionally seen it stated that there is no such right [to petition to the Mandates Commission], and, more frequently, that the Rules of Procedure were so rigid that they almost invariably nullified, in practice, the theoretical right which did exist.' in League of Nations, General Council, 'Fifth Meeting, 16 September 1927' 8 LNOJ 19.

58 See the President's speech in League of Nations, Permanent Mandates Commission, 'Minutes of the First Session 4-8 October 1921' Doc C.416.M.296.1921.IV, 2. 
obligations seriously..$^{59}$ The Commission's oversight, including the review of periodical reports, the petitioning system, and its focus on the well-being of the populations under the mandates system, may have been successful in inducing mandatory powers to comply with their obligations and improve the living conditions of these populations. For ease of administration, colonial powers often applied in their neighbouring colonies the obligations applicable to their mandates by creating administrative unions. ${ }^{60}$

Wilson's idealism is at the roots of the mandates system of the League of Nations. However, the departure from old practices was not complete. The non-application of the mandates system to the Allied powers' colonies is the most obvious evidence of this fact.

\section{The Mandates System of the League of Nations as a Continuation of Colonialism}

During the first session of the Permanent Mandates Commission, $M$ William Rappard, director of the mandates section of the Secretariat of the League, commented that

[t]he mandatory system formed a kind of compromise between the proposition advanced by the advocates of annexation and the proposition put forward by those who wished to entrust the Colonial territories to an international administration. ${ }^{61}$

Since its origins, the idealistic and innovative spirit of the mandates system had to accommodate the more traditional interests of the Allied powers. It is therefore not surprising that the mandates system still served their economic and political interests (3.1.). Moreover, the mandates system still relied on the criterion of civilization which justified colonialism (3.2.). This reliance, along with the lack of clear criteria for accession to independence made it difficult, if not impossible, for the mandates system to bring colonialism to an end (3.3.).

59 In 1924, Hugh Clifford, responsible for the administration of Nigeria, could not fail to observe that the obligations applicable to the 'Mandated Territory and the League of Nations stupidities ... despite their folly have to be treated seriously. 'Clifford to Gowers, 30 November 1924', in Gowers Papers, RH, Mss Afr S 1149. See also Callahan (n 21) 103.

60 Distefano (n 46) 872-873.

61 LoN, Permanent Mandates Commission, First Session (1921) (n 58) 4. 


\subsection{The Mandates System as a Formalization of the Interests of Colonial Powers}

Agreements conferring mandates were not concluded with the League but between mandatory powers and the Allied powers themselves. The refusal of the United States to accede to the Covenant of the League of Nations, as well as the desire of the Allied powers to keep full control of decisions relating to the fate of the territories under mandate, justified this choice. During the first session of the Permanent Mandates Commission, its members confessed that the Allied powers, not the League, were the ones in control of the mandates and that the League had been only entrusted with oversight and control powers over the system. ${ }^{62}$ The origins of the system leave no doubt on its consistency with the interests of the colonial powers themselves.

The allocation of territories placed under the mandates system closely followed the territorial interests of the mandatory powers. As those territories could not be annexed due to the principle of non-annexation, they were transformed into mandates of the state that had militarily occupied them during the war. ${ }^{63}$ Colonial powers did not see the institution as temporary nor as entailing any less control over territories under the mandates system than colonies. In 1926, the British Secretary of State for the Colonies, explained about Tanganyika, a B mandate, that:

Our mandate in Tanganyika is by no means temporary tenure or lease from the League of Nations. We hold it under obligation to the League, but in our own right under the Treaty of Versailles, and the foundations of East Africa for the future are as sure and as permanent in Tanganyika as any other of the East African territories. ${ }^{64}$

In a correspondence addressed to the Permanent Mandates Commission on the issue of nationality of the inhabitants of territories under mandate, the South African General Smuts said that '[w]e must only recognize the fact that $\mathrm{C}$ mandates are in effect not far removed from annexation. ${ }^{65}$ To use the words of Lord Balfour, colonial powers seem to have considered

62 ibid.

63 For information on the territories occupied by the Allied powers and the exchanges between them, see Wright (1930) (n 15) 26-27.

64 As quoted in EFW Gey van Pittius, 'Whither South-West Africa?' (1947) 23 Intl Affairs 202.

65 Smuts to Rappard (sent 4 July 1922), available in LoN, Permanent Mandates Commission, 'Minutes of the Second Session, 1-11 August 1922' Doc A.36.1922.VI[A], 91. 
the mandates system as a 'self-imposed limitation by the conquerors on the sovereignty which they obtained over conquered territory. ${ }^{66}$

In reality, the mandates did not imply an effective transfer of territory. It placed the territories concerned under an international legal regime. ${ }^{67}$ However, at the moment of the negotiations, the legal significance of the new regime was somewhat unclear. ${ }^{68}$ This constructive ambiguity facilitated its acceptance by Great Britain and France as a second-best alternative to dividing the territorial spoils of the war. In addition, there was no fixed deadline for the termination of the mandates, while the degree of international supervision over mandates remained unclear during the negotiations. Besides, no one could predict how the institution would develop in the future. ${ }^{69}$ Finally, the mandates system gave to mandatory powers a title to administer the territory at the exclusion of any other colonial power. Although it did not grant to mandatory powers the fulness of the territorial competencies inherent to sovereignty, mandatory powers still enjoyed a high level of control over the economic and political life of the territories under mandate. The $\mathrm{C}$ mandates were the ones with the least control over their internal affairs because they were fully subject to the laws of their mandatory powers, save only for some special protections. The B mandates were not subject to the laws of their mandatories, but the latter had never-

66 LoN, Council, 18th session, 11th meeting (17 May 1922) 3 LNOJ 547.

67 International Status of South-West Africa (n 1) 141. See also Marcelo G Kohen, Possession contestée et souveraineté territoriale (PUF 1997) 88-86.

68 Scholars from the time provided very different interpretations on the wording of Art 22 of the League Covenant and the nature of the mandates system. Among others, some scholars believed that sovereignty over territories under mandate belonged to the League (eg James C Hales, 'Some Legal Aspects of the Mandate System: Sovereignty-Nationality-Termination and Transfer' (1937) 23 Transactions of the Grotius Society 85; Hersch Lauterpacht, 'The Mandate in the Covenant' in International Law Being the Collected Papers of Hersch Lauterpacht vol. 3 (CUP 1977) 68-69; Ramendra Nath Chowdhuri, International Mandates and Trusteeship Systems (Martinus Nijhoff 1955) 8-10). For others, sovereignty rested with the populations of the territories under mandate (Duncan Campbell Lee, The Mandate for Mesopotamia and the Principle of Trusteeship in English Law (The League of Nations Union 1921) 19). A last group of scholars thought that sovereignty belonged to the mandatory powers (Quincy Wright, 'Sovereignty of the Mandates' 17 AJIL 691 (1923); Frederik Lugard, The Dual Mandate in British Tropical Africa (William Blackwood and Sons 1922) 50-59).

69 Andrew J Crozier, 'The Establishment of the Mandates System 1919-1925: Some Problems Created by the Paris Peace Conference' (1979) 3 J of Contemporary History 483,485 and 491 . 
theless full control over the administration of their territories. ${ }^{70}$ Even the A mandates, which were considered as quasi-independent territories, granted mandatory powers at least control over their military, ${ }^{71}$ over judicial system, ${ }^{72}$ and diplomatic affairs, ${ }^{73}$ as well as the right to draft some of their domestic laws. ${ }^{74}$

The mandates system also satisfied the economic interests of the states concerned. The internationalization of the status of the territories under mandate placed them beyond the sovereignty of the mandatory powers. Consequently, the latter could not discretionarily proclaim a monopoly of trade and commerce in these territories, as they could do with their colonies. One of the governing principles of the mandates system was openness to international commerce..$^{75}$ All mandates contained a clause guaranteeing to all members of the League of Nations freedom of trade and commerce in territories. ${ }^{76}$ As a consequence, even non-mandatory members of the League of Nations enjoyed the open-market policy applicable to these territories. Significantly, freedom of commerce and trade was established in territories under mandate, especially access to the Iraqi oil market, which was one of the main objectives of the United States in the negotiations. ${ }^{77}$

In sum, the international legal regime created by the mandates system allowed the accommodation of the different interests of the Allied powers. The idealism underlying the mandates system made way for pragmatism. It also succumbed to the prevailing prejudice and racial stereotypes prevailing during that period.

70 See, eg, art 9 of the 1922 French Mandate for Togoland (n 42).

71 Art 2 of the 1922 French Mandate for Syria and the Lebanon (n 40); art 17 of the 'Mandate for Palestine (24 July 1922) Doc C.252.1922.VI; art 7 of the 1922 Treaty of Alliance (Great Britain-Iraq) (n 42).

72 Art 6 of the 1922 French Mandate for Syria and the Lebanon (n 40); arts 1 and 14 of the 1922 Mandate for Palestine, ibid; art 9 of the 1922 Treaty of Alliance (Great Britain-Iraq) (n 42).

73 Arts 3, 4, 5, and 7 of the 1922 French Mandate for Syria and the Lebanon (n 40); art 12 of the 1922 Mandate for Palestine, ibid; arts 4 and 5 of the 1922 Treaty of Alliance (Great Britain-Iraq) (n 42).

74 Arts 1, 14 and 15 of the 1922 French Mandate for Syria and the Lebanon (n 40); arts 1 and 21 of the 1922 Mandate for Palestine, ibid; arts 3 and 14 of the 1922 Treaty of Alliance (Great Britain-Iraq) (n 42).

75 See LoN, Permanent Mandates Commission, First Session (1921) (n 58) 4.

76 See, eg, art 6 of the 1922 French Mandate for Togoland (n 42).

77 See John A DeNovo, 'The Movement for an Aggressive American Oil Policy Abroad, 1918-1920' (1956) 61 Am Historical Review 854, 861. 


\subsection{The Reliance of the Mandates System on the Right of Civilization}

Despite their divergence on the principle of annexation, the Allied powers agreed all on the existence and the practical consequences of the right of civilization. Since 1492, colonial powers had justified colonialism through a theory of social evolution that put European civilization at the apex of a purported universal standard of human civilization. Thus, during the Spanish epoch of international law, populations considered as slaves by nature, in light of their sociopolitical organization, were deemed incapable of governing themselves. ${ }^{78}$ The papal bull Inter Caetera of 1493 implemented this worldview when Alexander VI granted to the Spanish Sovereigns sovereignty over the territories of the populations encountered by Christopher Columbus during his first trip to the Americas. The mission assigned to King Ferdinand and Queen Isabella was to instruct them in the Catholic faith and train them in good morals.79 Since then, the right of civilization has remained a constant feature of European colonial ideology. 80

The mandates system endorsed the criterion of civilization in at least two ways. First, the mandates system categorized the populations of the territories under mandate in accordance to their degree of civilization. The initial draft of Article 22 of the Covenant, which was proposed by General Smuts, was based on the idea that certain races were incapable of ever becoming fully civilized. Smuts proposed, therefore, the annexation of German colonies and the transitional application of the mandates system only to former empires, such as Austria-Hungary and Turkey. ${ }^{81}$ The last version of Article 22, granting independence to nations under the Austrian-Hungarian Empire, and applying the mandates system to former colonies, was a result of the pressure imposed by the United States. ${ }^{82}$

78 On this issue, see Mamadou Hébié, Souveraineté territoriale par traité: une étude des accords entre puissances coloniales et entités politiques locales (PUF 2015) 130-136.

79 'Bull Inter Caetera of Pope Alexander VI, 4 May 1493', in Wilhelm Grewe (ed), Fontes Historiae Iuris Gentium: Sources relating to the History of the Law of Nations (Vol 2, Walter de Gruyter 1988) 108 (Doc 10).

80 Jo-Anne Claire Pemberton, 'The So-Called Right of Civilisation in European Colonial Ideology, 16th to 20th Centuries' (2013) 15(1) JHIL 25-52.

81 Jan C Smuts, The League of Nations: A Practical Suggestion (London \& Stoughton 1918) 15.

82 According to Wright, although the final version of Article 22 was introduced by Lloyd George, its drafting was actually mostly done by Smuts, thus making Smuts the one to prepare both the original and the final drafts of Article 22. See Wright (1930) (n 15) 32. 
Article 22 of the League Covenant distinguished between A, B, and C mandates. Class A mandates were composed of '[c]ertain communities formerly belonging to the Turkish Empire [which had] reached a stage of development where their existence as independent nations [could] be provisionally recognized'. Although the communities that formed part of this class still needed the administrative advice and assistance of a mandatory power, their wishes had to be a 'principal consideration in the selection of the mandatory. Class B mandates were composed not of 'communities', but of 'peoples' which were considered to be 'at such a stage that the Mandatory must be responsible for the administration of the territory' under certain international safeguards stipulated for their inhabitants. As for Class C mandates, they were merely referred to as

territories, such as South-West Africa and certain of the South Pacific Islands, which, owing to the sparseness of their population, or their small size, or their remoteness from the centres of civilisation, or their geographical contiguity to the territory of the Mandatory, and other circumstances, can be best administered under the laws of the Mandatory as integral portions of its territory, subject to the safeguards above mentioned in the interests of the indigenous population.

Secondly, the identification of the states fit to act as mandatory powers was equally based on the criterion of civilization. Only states ruled by Europeans or their descendants were entitled to act as mandatories. Japan is the only exception to this rule. Japan had adopted the European standard of civilization and was considered to have made progress in this regard. ${ }^{83}$ Despite the rejection of the Japanese proposal for the inclusion of a clause on the equality of races in the Covenant, ${ }^{84}$ Japan was still considered as an 'advanced nation' under Article 22 of the Covenant, and therefore capable of undertaking the tutelage of populations 'not yet able to stand by themselves under the strenuous conditions of the modern world'.

83 On Japan's process of westernization, see Susumu Yamauchi, 'Civilization and International Law in Japan During the Meiji Era (1868-1912)' (1996) 24 Hitotsubayashi Journal of Law and Politics 1-25.

84 'Preliminary Peace Conference, Protocol No 5, Plenary Session of April 28, 1919', in Office of the Historian, Papers Relating to the Foreign Relations of the United States, The Paris Peace Conference, 1919 (Vol 3), File no Paris Peace Conf.180.0201/5, at 289-291 <https://history.state.gov/historicaldocuments/frus1919Parisv 03/d7> accessed 21 November 2018. See also Castellanos-Jankiewicz (ch 5). 
Japan was therefore assigned some of the $\mathrm{C}$ mandates over the Pacific Islands. ${ }^{85}$ States that were part of the British Empire became responsible for the other C mandates: South West Africa was assigned to South Africa, ${ }^{86}$ New Guinea to Australia, ${ }^{87}$ Western Samoa to New Zealand, ${ }^{88}$ and Nauru to Great Britain. ${ }^{89}$ Among the B mandates, 'East Africa' was awarded to Belgium ${ }^{90}$ and Great Britain. ${ }^{91}$ Cameroon $^{92}$ and Togoland ${ }^{93}$ were divided among Great Britain and France. Finally, the A mandates of Iraq ${ }^{94}$ and Palestine $^{95}$ were also granted to Britain, while France kept the SyrianLebanese mandate. ${ }^{96}$

Article 22 of the Covenant gave a conventional foundation to the right of civilization and categorized the populations of the territories under mandate based on their level of sociopolitical development. As the mandates system relied heavily on the very ideology which had justified colonial expansion, it could not bring it to an end.

\subsection{The Mandates System as an Entrenchment of Colonial Domination}

While during colonial expansion a 'backward nation' could be placed summarily under the sovereignty of a colonial power, advocates of the mandates system believed that societies evolved in a Darwinist manner. Just like children are only able to fully exercise their personality rights when they reach a certain age, a given society would only be able to fully become independent upon reaching a certain level of civilization, as defined

85 Mandate for the German Possessions in the Pacific Ocean Lying North of the Equator (17 December 1920) 2 LNOJ 84, 87.

86 'Mandate Agreement Regarding German South West Africa' (17 December 1920) 2 LNOJ 84, 89.

87 'Mandate for the German Possessions in the Pacific Ocean Situated South of the Equator, Other than German Samoa and Nauru' (17 December 1920) 2 LNOJ 84, 85.

88 'Mandate for German Samoa' (17 December 1920) 2 LNOJ 84, 91.

89 'Mandate for Nauru' (17 December 1920) 2 LNOJ 84, 93.

90 'Belgian Mandate for East Africa' (1 October 1922) C.449.(1)f.M.345(f).1922.VI..

911922 British Mandate for East Africa (n 41).

921922 British Mandate for the Cameroons (n 41); 'French Mandate for the Cameroons' (1 October 1922) C.449.(1)e.M.345(e).1922.VI.

931922 French Mandate for Togoland (n 42); 'British Mandate for Togoland' (1 October 1922) C.449.(1)b.M.345(b).1922.VI.

941922 Treaty of Alliance (Great Britain-Iraq) (n 42).

951922 Mandate for Palestine (n 71).

961922 French Mandate for Syria and the Lebanon (n 40). 
through European lenses. Although theoretically possible, independence remained largely an illusion.

The division of mandates in Article 22 of the League Covenant presumed that territories under mandate should, and eventually would, follow a linear development towards the European standard of civilization or, in the words of Article 22, until they were 'able to stand by themselves under the strenuous conditions of the modern world'. Under this logic, C mandates would eventually evolve to $\mathrm{B}$, and then to A mandates, and would be terminated once they had achieved the required level of civilization. However, neither the League Covenant nor the mandate agreements clarified under what conditions a class A mandate would be considered fulfilled and terminated. The A mandate agreements, the only ones to have any mention of the possibility of independence, merely provided that, upon the end of the mandate, the Council would continue to monitor and pressure mandatory powers to fulfill their international obligations. ${ }^{97}$

The lack of any provision on how to terminate mandates or to upgrade a territory from one category to the other suggests that a subsequent agreement or an amendment to article 22 of the League Covenant would be necessary. Such a negotiation would, therefore, be political, rather than legal, and would rely largely on the impressions and political will of the members of the League.

During the entire existence of the mandates system, the only territory under mandate which became independent was Iraq, an A mandate that was under Great Britain's administration. The termination of Iraq's mandate and approval of its membership to the League was described by member states as an evolution from 'adolescence to the full status of manhood' It was also presented as evidence that the mandates system was not a cloak perpetuating colonial domination..$^{98}$

Great Britain advocated for Iraq's independence before the Permanent Mandates Commission and the League Council. ${ }^{99}$ Its decision to withdraw from Iraq, however, was less motivated by actual confidence in Iraq's capacity to 'stand on its own' than by Great Britain's financial difficulties in keeping a governmental structure in Iraq, coupled with the Iraqi resistance

97 Art 19 of the 1922 French Mandate for Syria and the Lebanon (n 40); art 28 of the 1922 Mandate for Palestine (n 71).

98 League of Nations, Permanent Mandates Commission, 'Minutes of the TwentySecond Session, (3-6 November 1932)' C.772.M.364.1923.vi, at 37.

99 For details on the negotiations on Iraq's independence at the League of Nations, see Susan Pedersen, 'Getting Out of Iraq-in 1932: The League of Nations and the Road to Normative Statehood' (2010) 115 The Am Historical Review 975. 
to British presence. The resistance to foreign intervention had already granted Iraq considerable advantages when compared to other mandates. Along with Syria, Iraq was the only territory under mandate that had its sovereignty officially recognized ${ }^{100}$ and that had the right to conduct its diplomatic relations, albeit under limited British supervision. ${ }^{101}$ Still, when negotiating the termination of the mandate, Iraq had to grant to Great Britain a series of military and economic concessions that survived the mandate. ${ }^{102}$ Iraq's independence was, therefore, attributable to particular circumstances, and not to an alleged right to independence under the mandates system.

The absence of a concrete right to independence under the mandates system has an important theoretical consequence. Despite several references to 'self-determination' or to the word 'people' during the period of the League of Nations, there is no filiation between those references and the principle of equal rights and self-determination of peoples consecrated as an objective of the Organization under Article 1, paragraph 2 of the United Nations Charter. Thus, the Court explained in the Namibia advisory opinion that it is ' $[t]$ he subsequent development of international law in regard to non-self-governing territories, as enshrined in the Charter of the United Nations', which made 'the principle of self-determination applicable to all of them.' ${ }^{103}$ However, the Charter itself did not impose decolonization. ${ }^{104}$ Similarly to the mandates system, it continued to regulate colonialism. Under Article 73 of the Charter, states administering non self-governing territories 'recognize[d] that the interests of the inhabitants of these territories are paramount' and 'accept[ed] as a sacred trust the obligation to promote to the utmost ... the well-being of the inhabitants of these territories. Consequently, under Article 73 (b) administering powers accepted to 'develop self-development ... and to assist [the peoples of non-self-govern-

100 League of Nations, Permanent Mandates Commission, 'Minutes of the TwentySecond Session' (3-6 November 1932) C.772.M.364.1923.vi, at 37.

101 Art 5 of the 1922 Treaty of Alliance (Great Britain-Iraq) (n 42). PMC, Seventh Session (1925) (n 53).

102 Treaty of Alliance (Great Britain and Iraq) (signed 30 June 1930) [1932] CMD.3797.

103 Legal Consequences or States of the Continued Presence of South Africa in Namibia (South West Africa) notwithstanding Security Council Resolution 276 (1970) (Advisory Opinion) [1971] ICJ Rep 31 [52].

104 Huntington Gilchrist, 'Colonial Questions at the San Francisco Conference,' (1945) 39 American Political Science Review 982, at 987; Michel Virally, 'Droit international et décolonisation devant les Nations Unies' (1963) 9 AFDI 508, 509. 
ing territories] in the progressive development of their free political institutions.' Under Article 73 (e), administering powers accepted 'to transmit regularly to the Secretary-General for information purposes, subject to such limitation as security and constitutional considerations may require, statistical and other information of a technical nature relating to economic, social, and educational conditions in the territories.' None of these obligations can be equated with an obligation to decolonize. It is only with the adoption of Resolution 1514 (XV) by the General Assembly that

the international law of self-determination developed in such a way as to create a right to independence for the peoples of non-self-governing territories and peoples subject to alien subjugation, domination and exploitation. ${ }^{105}$

Resolution 1514 (XV) rejected the idea of a universal concept of civilization. Giving full meaning to the principle of equal rights of peoples and self-determination, it declared that '[i]nadequacy of political, economic, social or educational preparedness should never serve as a pretext for delaying independence. ${ }^{106}$

The entire social Darwinism underlying the mandates system had finally been set aside. With Resolution 1514 (XV), the United Nations established the right to self-determination as a right of peoples to freely determine their political status and freely pursue their economic, social and cultural development.

\section{Conclusion}

You cannot put new wine into an old wineskin. Old wineskins have suffered from fermentation; they have been stretched to their limits and are brittle. Putting new wine into them would most probably tear them apart, thus losing both, the wine and the wineskin. The only way of effectively preserving new wine is by putting it into a new skin that is ready to accommodate it. The link between wines and wineskins reflects a common issue involving new ideas and old institutions. New ideas and paradigms usually arise and are first implemented in traditional contexts and institutions that

105 Accordance with International Law of the Unilateral Declaration of Independence in Respect of Kosovo (Advisory Opinion) [2010] ICJ Rep 436 [79] (emphasis added).

106 United Nations, General Assembly, 'Resolution 1514, Declaration on the Granting of Independence to Colonial Countries and Peoples' (14 December 1960) UN Doc A/RES/1514(XV). 
were not designed nor prepared for them. They have been developed to sustain old paradigms and their structures lack the plasticity to adapt to new ones. As a result, these old structures may end up contaminating these new paradigms and their implementation up to the point of distortion.

The mandates system was, in this sense, some drops of new wine in the old wineskin containing colonialism, not enough to tear it or to fundamentally change its content and nature. The principle of non-annexation that the mandates system embraced was a right step towards the universalization of the prohibition of the acquisition of territorial sovereignty through the use of force. The Permanent Mandates Commission provided the first laboratory of an institutional mechanism for the protection of human rights at the international level. A century later, the periodic reports system and the right to petition at the international level, despite their imperfections, remain established features of quasi-judicial human rights monitoring bodies. 
